\title{
俳句の漢訳における諸問題
}

松尾芭蕉を例にして

Weihong ZHU(朱衛紅 : Associate Professor, Shanghai University of Finance and Economics)

范huwh@mail.shufe.edu.cn

(中国) 上海財経大学外国語学部准教授、日本文化研究所所長。(日本)筑波大学出身、文学博士。日本 文学研究、詩歌の翻訳研究。主著に「現代短歌に詠われた「上海」一現代歌人たちの中国旅行詠を分析して」 (『文学研究論集』 2013.3)、「詩歌における言語内翻訳の可能性に関する考察—『チョコレート語訳・みだれ髮』 を例にして—」(『文学研究論集』2009.3)、「『車塵集』における古典和歌との交渉」『文学研究論集』、2000.3) など。科学研究費補助金に日本現代短歌における中国の表象、中国国家社科基金2013.6-2019.6など。

\section{A Comparative Study of the Difficulty of Translating Haiku}

It is generally considered difficult to translate poetry, and even more so to translate the Haiku. This is a traditional form of Japanese poetry which is composed of only 17 syllables over three lines, in a "5-7-5" pattern. Therefore, the Haiku is the shortest form of poem in the world. In addition to brevity, it also has the salient characteristics which result from vagueness. Matsuo Bashō has been called "the greatest master of Haiku", and his poems are not only brief and vague, but also full of "Zen" (meditation), because he was significantly influenced by the thought of Zhuangzi. In the 1920s, Zuoren Zhou, a famous Chinese translator, published "Japanese Poetry" in order to promote Japanese Haiku in China. In that article, Zhou included translations of seven Haikus of Matsuo Bashō. This study compares Zhou's seminal translations with the translations of other contemporary translators (i.e., Minxin Zheng, Lin Lin, and Yuan Tian), in order to examine the difficulties of translating Haiku in three respects: rhythm, Kigo (season-related words), and Kireji (cutting words).

Keywords Haiku(俳句), Chinese translation(漢訳), Rhythm(音律), Kigo(季語), Kireji (切れ字) 


\section{1 はじめに一問題提起}

俳句は短歌と共に日本固有の短詩文芸である。その完成に多大な貢献をした人物が松 尾芭蕉であった。彼はまず、俳句の実作者としてすぐれていた。彼の詠み残した俳句 は、1千句ほどが現存する。多くの日本人はそれらを暗記しており、折に触れて心のふ るさとを懐かしむかのように口に出したりする。その意味で芭蕉が日本の生んだ最高の 詩人の一人だったことは間違いない。彼はまた、俳句の制作のために集まった仲間たち を統率し、俳句という文芸を理論的に深化、確立させる上での優秀な組織指導者でも あった。

欧米諸国のアジアへの進出に対して社会変革を実施し近代化に成功した日本は、20世 紀に入る頃には世界の有力国として名乗りを上げ始めた。これが中国人が近代日本を意 識した最初の機会になる。中国の若者たちが大挙して日本へ留学した。その中には後に 中国を代表する文豪となる魯迅や、弟の周作人らもいた。周作人の留学は、1906 11年 の5年間であったが、帰国後の1920年代に芭蕉や一茶らに触れた文章を書き残してい る。これが中国人による芭蕉を論じた最初の本格的な足跡であった。

周作人に続く人物はしばらく現れなかった。時代は日本が中国を侵略しようとした 15年戦争の時期である。さらに第二次世界大戦の終了後には、新中国の成立が続き、中 日の文化交流はほとんど途絶えたままの状態であった。1980年前後から中国が改革開放 の時代となり、60年近い長い空白を経てやっと中日の交流が再開された。その成果の一 つとして、この40年間に中国人によって数冊の芭蕉に関連した書籍が出版されている。 それらの著者名と書籍名、出版年を以下に列挙する。林林 ${ }^{\circledR}$ 日本古典俳句選』(1983) と彭 恩華『日本俳句史』(1983)、間をおいて鄭民欣『俳句的魅力一一日本名句賞析』(2008)が続 く。最初の二冊は改革開放後の日本ブームの一環であった。鄭民欣はもともと漢詩人で あり、日本の伝統詩を勉強した上で翻訳した。俳句に加えて、短歌の本も出しており、 具体的に俳句を引き、それについて自分の鑑賞を付け加えている。近年、この種の書籍 の出版が急増している。鄭茂清『芭蕉百句』(2017)、姜文清『日本俳句長編』(2018)、今年 に入ってからも陳黎『松尾芭蕉俳句300但願呼我的名為旅人』(2019)、田原『松尾芭蕉俳句 選』(2019)などと続く。これらの翻訳者は日本へ留学していたり詩人だったり、また鄭 茂清と陳黎は同じ漢語系でも台湾の出身である。総体としてこれらの人たちは前の世代 よりも自由な翻訳を目指している。

周作人は「日本的詩歌」 ${ }^{1}$ と日本的小詩」 ${ }^{2}$ 二論文で日本の俳句を紹介した。その中で 以下のような芭蕉の俳句を7句翻訳している。

\footnotetext{
1 周作人「日本的詩歌」（『説月報』12(5)，1921.5)。周作人「日本的詩歌」(鐘叔河編『周作人文類編7, 日本管窺」 湖南文芸出版社, 1998)を参照。

2 周作人「日本的小詩」(『晨報副刊』1923.4. pp.3-5)。前掲書を参照。
} 
1. 古池や蛙飛び込む水の音

2. 名月や池をめぐりて夜もすがら

3. 初しぐれ猿も小䒾をほしげなり

4. 枯枝に鳥のとまりたるや秋の暮

5. 憂き我をさびしがらせよ閑古鳥

6. 塚もうごけわが泣く声は秋の風

7. 旅に病んで夢は枯野をかけめぐる

論末に周作人が翻訳したこの7句を前揭の7書籍が如何に翻訳し直しているかを対比し た資料(付録：芭蕉漢訳例一覧)を添付した。これを基礎資料にして俳句を漢訳する際に 生じる幾つかの諸問題を考察することが本論の目的である。

\section{2 音数律の問題}

俳句は、 $5 \cdot 7 \cdot 5$ 音節数によるリズムを持つ定型詩である。周作人は一世紀も前の 先駆者であるため、最近の俳句漢訳を考える上では例外となる。彼を含めて 8 人が、音 数律という観点からどのように俳句の漢訳をしているかをまとめたのが、【表1】であ る。

【表1】音数律からみた漢訳俳句表(改行の場合「・」。訳がない場合「メ」)

\begin{tabular}{|l|l|l|l|l|l|l|l|l|l|}
\hline 訳者 & 句1 & 句2 & 句3 & 句4 & 句5 & 句6 & 句7 & 行 & 音数律 \\
\hline 周作人 & 12 & 15 & 17 & 13 & 13 & 13 & 13 & 1 & \\
\hline 彭恩華 & $5 \cdot 5$ & $5 \cdot 5$ & $x$ & $5 \cdot 5$ & $5 \cdot 5$ & $5 \cdot 5$ & $7 \cdot 7$ & 1 行2分 & 0 \\
\hline 林林 & $4 \cdot 7$ & $3 \cdot 5$ & $4 \cdot 6$ & $5 \cdot 5$ & $x$ & $5 \cdot 8$ & $5 \cdot 5$ & 2 & \\
\hline 鄭民欣 & $x$ & $x$ & $5 \cdot 5$ & $x$ & $5 \cdot 8 \cdot 5$ & $5 \cdot 7 \cdot 5$ & $5 \cdot 5$ & 2 と3 & \\
\hline 鄭清茂 & $\times$ & $4 \cdot 6 \cdot 4$ & $4 \cdot 6 \cdot 4$ & $4 \cdot 6 \cdot 4$ & $4 \cdot 6 \cdot 4$ & $x$ & $4 \cdot 6 \cdot 4$ & 3 & 0 \\
\hline 姜文清 & $3 \cdot 4 \cdot 3$ & $3 \cdot 4 \cdot 3$ & $3 \cdot 4 \cdot 3$ & $3 \cdot 4 \cdot 3$ & $3 \cdot 4 \cdot 3$ & $3 \cdot 4 \cdot 3$ & $3 \cdot 4 \cdot 3$ & 3 & 0 \\
\hline 陳黎 & $2 \cdot 4 \cdot 3$ & $4 \cdot 2 \cdot 2$ & $7 \cdot 6 \cdot 3$ & $2 \cdot 3 \cdot 2$ & $4 \cdot 6 \cdot 4$ & $5 \cdot 2 \cdot 5$ & $4 \cdot 7 \cdot 5$ & 3 & \\
\hline 田原 & $3 \cdot 7$ & $4 \cdot 5 \cdot 4$ & $4 \cdot 7$ & $5 \cdot 5$ & $5 \cdot 7 \cdot 4$ & $5 \cdot 4 \cdot 3$ & $5 \cdot 8$ & 2 と3 & \\
\hline
\end{tabular}

表から読み取れることを以下に列挙する。まず、周作人の訳は、日本語で元の俳句 がどのような意味内容なのかを説明するために示した訳文であり、単独の翻訳詩として 提示したものではない。17音の俳句の漢訳が、13音ほどで済んでいる。

一定の音節数によってリズムを組み立てる音数律の定型訳は、 $5 \cdot 5$ 音の彭恩華 $(7 \cdot 7$ の例外が一句) と $4 \cdot 6 \cdot 4$ 音の鄭清茂、 $3 \cdot 4 \cdot 3$ 音の姜文清の 3 人。残りの林林、鄭民欣、陳

3 日本の伝統詩の翻訳について、彼は「不満があるが、散文で大意を説明する以外に適当な方法はない」と述 べている(同注1, p .253)。 
黎、田原の4人は句によって音数を使い分けており、定型でない自由律詩と考えた ${ }^{4}$ 。 次に訳された詩が2行訳か、3行訳かという問題を検討した。彭恩華は1行書きだが、 1行の間に空白を入れ2分割しており、2行側に含めた。彭恩華、林林、田原の3人が2 行、鄭清茂、姜文清、陳黎の3人は3行。鄭民欣は両方で訳している。

7人で7句を翻訳し、訳の欠けている句もあるため、全部で42の翻訳句があり、総行 数にすると108行ある。各行で音数が、最短の行は2音が6例で、最長の行は8音が3例あ る。漢訳は短くて済むにしても常識的には、1行が2音は短過ぎるだろうし、逆に1行が8 音は長過ぎると考えられる。どちらも訳者が意図的に短くしたり長くしたりしていると 考えられる。短いのはその言葉を強調したい例、長いのはその句に対する訳者独自の解 釈を付け加えている例などがありえよう。漢訳された42句の総音数は、490音である。 一句当たりの音数は、平均値で11.67、つまり17音の俳句を漢訳すると、12音弱で翻訳 できる計算で、3割弱の削減になる。

幾つかの問題点を挙げてみたが、当然のことながら、これらの問題は漢語と日本語 の言語としての相違に起因している。各々の言語の特質を集約して体現しているのが、 それぞれの伝統詩に外ならない。中国の伝統詩は1行が5言か7言、絶句は4行で、律詩は 8行の定型詩である。このように絶句や律詩には、1首の行数や 1 行の語数に音数律の規 則があり、この点は日本の伝統詩と共通する。さらに言うと、漢語も日本語もその1音 節1音節が区別しやすい言語である。俳句の漢訳に際し 7 人中 3 人が、今も音数律で訳し ているのはそのためもあろう。しかし、音数律以上に中国詩にとっては、各語の平入の 整斉さや句末の押韻による韻律の方が重要である。漢語の基本音節は約500あり、同一 の音節に四声・平入の区別が存在し、4種類の声調で言い分けられる。これら数千種類の 音節を効果的に交響させる韻律によって、表現に音楽的な美を整えるのが、中国の伝統 詩の特色なのである。

日本の伝統詩には音響による韻律はなく、音節の数による音数律しかない。伝統詩が このような音数律のみに支えられているのは、もちろん日本語の音節構造に由来してい る。五十音図で示される日本語の音節はおよそ100個、その数が圧倒的に少ない。さら に日本語の音節の大部分は、母音または二重母音で終わるため、音韻的な変化も乏し い。ならば、日本の伝統詩を理解する鍵は何かと言えば、それは助詞や助動詞の果たす 役割にある。

漢語の文法構造は比較的簡単であり、単語は実質的な意味を示すだけであり、語尾変 化や接辞がなく、文法の機能は主として配列の語順によって表される。名詞の格や数や 性、動詞の時制や態や法などの関係を示す具体的な目印はすべて省略され、聞き手の判 断に任される。その意味で表現は整然かつ簡潔である。このような言語は孤立語といわ

4 この4人の訳した前記の4書籍をそれぞれ音数から統計してみた。その内、林は219句を訳したが、音数の 配列が39種類、一番多い配列は5・5音(42句)、鄭は29句を訳したが、音数の配列が7種類、一番多い配列 は $5 \cdot 7 \cdot 5$ (11句)、田は200句を訳したが、音数の配列が77種類、一番多い配列は 5 ・5音 (13句)、陳は300 句を訳したが、音数の配列が 164 種類、一番多い配列は $4 \cdot 6 \cdot 4$ 音 $(12$ 句)。 
れ、漢語の他にチベット語やタイ語が含まれる。それに対して日本語は、膠着語といわ れる言語であり、語の順序や語尾変化ではなく、助詞や助動詞などの付属語が付くこと によって文法的機能が明示される言語である。そのため文の成立について助辞が果たす 機能が大きく、助詞や助動詞を添付することで微妙な表現をいい分けることができる。 漢語にはこの助詞や助動詞、それに活用語尾などはすべてなく、その構造が同じことを いうのなら、漢語文が日本語文より簡潔で短くなり、漢訳俳句は日本語俳句の7割で可能 だということになる。

\section{3 季語の問題}

俳句は、一句の中に必ず一つ季語といわれる季節のことばを用いる約束になってい る。何人かで長句 $(5 \cdot 7 \cdot 5)$ と短句 $(7 \cdot 7)$ を交互に付けつらねて、100句とか36句とかで 一巻を完成させるのが、俳諧連歌であった。季語は発句と呼ばれるその最初の句に、 「時候の挨拶」を詠みこむ必要から生じた。発句だけを独立させて俳句が成立する過程 で、季語を詠み込むという約束はそのまま継承された。したがって季語は、作り手と読 み手をつなぐキーワードの役割を担っている。季語を集めて分類し、解説と例句を添え た歳時記と呼ばれる書籍が今も多数出版されている。長い時間の中で選びとられ集積さ れた季語という詩語は、イメージ性の豊かな文化体系の核に他ならない。時々の触れ合 いの中で詩情を喚起し、風土に育てられた日本人に潜在する語群である。俳句の鑑賞に は、まず季語に注目し、季語の共時的な情趣を探ると同時に奥を流れる通時的な情感を 把握し、作者が託した心情を吟味することが必要である。

芭蕉の俳句の漢訳において、季語がどのように訳し換えられているかを整理したの が、【表2】である。

【表2】季語の訳例一覧表(複数人の場合後ろの数字で表す)

\begin{tabular}{|c|c|l|}
\hline 俳句 & 季語 & 訳例 \\
\hline 1 & 蛙 & 青蛙 (5)、蛙 \\
\hline 2 & 名月 & 中秋明月 (2)、秋月 (2)、十五夜的明月、明月、中秋圆月 \\
\hline 3 & 初しぐれ & $\begin{array}{l}\text { 下时雨初初寒降雨、入冬初降雨、初逢时雨、冬雨下、初冬第一场阵雨一、 } \\
\text { 冬季秋雨 }\end{array}$ \\
\hline 4 & 秋の暮 & 秋天的晚、秋日今向暮、深秋日暮时、秋日黄昏、暮秋中、秋暮、秋日入黄昏 \\
\hline 5 & 閑古鳥 & 闲古鸟、布谷鸟声声鸣不停、闲古鸟鸣、杜鹃鸟、啊, 布谷鸟一、布谷鸟鸣 \\
\hline 6 & 秋の風 & 秋风中(2)、秋风 (2)、秋的风、共秋风、化作秋风萧瑟声、化秋风 \\
\hline 7 & 枯野 & 枯野(4)、荒野(3)、荒原 \\
\hline
\end{tabular}

俳句1の季語は「蛙(かわず)」。かつては「かじかガエル」のことを指したが、平安期以 
後、蛙一般を指すようになった。それに対して、漢語「青蛙」は『新華辞典』によれば、 「種類が多くあるが、「青蛙」はよく見られる一種だ」と説明されており、普通の蛙として 5人の訳者が「青蛙」と訳した。このように季語の日本語に対応する漢語があれば、それ を使えばよい。俳句6の季語「秋風」もその例である。この語は中国こそが本家である。 中国の詩文で万物を零落させ、肃殺を持って心とする語とされており、芭蕉たちはその 影響から「秋風」に悲愁の心を託すことが多くあった。

漢語に俳句の季語である言葉があるが、使い方のずれがある場合もある。例えば、 俳句3の季語「初時雨」はその年の冬の最初に降る雨、季語としては「時雨」に含まれる。 もともとこの語は、中日両方で一時的に降ったり止んだりする雨の意味で使われ、初冬 に限った言葉ではなかった。この「初時雨」にはとうとう冬になったという季節への感慨 が込められている。それが日本では中世以降この雨には、ものみな枯れつつある時の わびしさがあるとし、俳句に携わるものにとっては詩情を掻き立てる力を持つ重要語へ と変化し、中日の間で意味にズレが生じた。そのずれを埋めるべく漢訳は「下时雨初」 (時雨が降りはじめた頃)、「初寒降雨」(寒くなり始めた頃の雨)、「入冬初降雨」(冬に入り 初めて降った雨)、「初逢时雨」(初めて時雨に遭う)、「冬雨下」(冬の雨が降っている)、「初 冬第一场阵雨—」(初冬初めてのにわか雨)、「冬季秋雨」(冬の季節秋の雨)などと、大切 な言葉だけに様々に工夫している。

俳句4の季語「秋の暮」は、秋の終わりと秋の夕暮れという二つの意味を持っている。 芭蕉も暮秋・秋夕の両方の意味で用いていた。漢語の「秋暮」にも「秋の終わり」と「秋の夕 暮れ」というふたつの意味がある。訳者らはこの言葉の微妙な違いを訳し分けたいので あろう。「秋天的晚」(秋の夕方)や「秋日今向暮」(秋日暮れようとしている時)、「秋日黄昏 」(秋の黄昏)、「秋日入黄昏」(秋の日の黄昏になる時)のように「秋の夕暮れ」の意味にする 訳と、「暮秋中」のように「秋の終わり」の意味にする訳、「深秋日暮时」(晚秋日の暮れる 時)のように両方の意味を表そうとしている訳、あるいは「秋暮」をそのまま使って曖昧 にしている訳、とばらつきがある。

漢語に俳句の季語である言葉はない場合もある。例えば、俳句7の季語「枯野」であ る。花も紅葉も消え去った冬の野原で、枯れ草が俶しい音を立てる。枯野が盛んに詩歌 に詠まれるようになったのは、中世以降である。この言葉も日本語的に「枯野」(4) と訳 した者と、漢語的に「荒野」(3)、「荒原」と訳した者とがいる。

俳句2の季語「名月」は陰暦8月15日の明るく美しい月を指す言葉である。漢語には「名 月」という言葉がないため、訳語は「十五夜的明月」(十五夜の明月)や「中秋明月」、「秋月」、 「明月」、「中秋圆月」(中秋満月)などと訳している。俳句5の季語「閑古鳥」は「郭公」(かっ こう)の異称である。明るい林や草原にいて「カッコーカッコー」と鳴く。そののどかな 鳴き声から「閑古鳥」と呼ばれた。漢語に「閑古鳥」という言葉はないが、「杜鹃鸟」「時鳥」 「子規」「杜宇」「布谷」等の言葉はある。日本人は「閑古鳥」を夏鳥と考えたが、中国人は「杜 鹃岛」を春鳥と考える。ここで巴蕉が閑古鳥という異名を使ったのは、当て字ではあっ 
ても、表記にワビサビに通じる閑」という字が使われていたからであろう。それを理 解した者は閑古鳥とし、中国人にわかるようにと考えた者は「布谷鸟」「杜鹃岛」と訳して いる。

中国と日本とは一時間の時差があり、成田から上海まで飛行機だと3時間を要す。中 国が大陸国なのに対し、日本は島国である。同じ東アジアといっても地理的風土的に相 違がある。さらにまた、中国と日本はよく同種同文といわれる。確かに日本は1700年以 上も前から中国生まれの漢字といら文字を移入し、様々な工夫をしながら日本語を書き 表してきた。漢字で書かれた季語がそのまま中国人に通じる場合もないわけではない。 しかし、長い歴史の中で中国にはないような、日本独特の漢字の用法を多方面にわたっ て発達させている。漢字で書かれても、中日でその意味にズレや違いがある場合もあろ う。「閑古鳥」や「枯野」は歳時記にあるが、「布谷岛」「杜鹃岛」だけではなく、「荒野」も俳 句の季語としては認められていないのである。

\section{4 切れ字の問題}

季語と並んで、俳句の秘密を解く重要なキーワードとされるのが切れ字である。季 語が句の主題に関連する言葉だとするならば、切れ字はその主題を如何に提示するかと いう構成原理に関係する。文字通り句を切るための言葉であり、5・7・5の句を初めか ら終わりまでそのまま進ませずに、途中でいったん止めてしまう働きをする。切れ字 によって句は、そこまでの前半と、あとの後半に切断される。前半と後半に異質なもの ごとが配置される構成である。前半を読んで来たところが切机字によって切断され、そ こまでが反忽され濃縮されたところへ、異質な後半が重なって、その対立交響によって 詩情が増幅されるという重複構造である。

芭蕉の俳句で実際にどれが切れ字かは、以下の2本線を引いた部分である。

1.「古池や…」名月や…「枯枝に鳥のとまりたるや…」(助詞「や」)

2.「憂き我をさびしがらせよ‥」塚もうごけ…（助動詞「す」動詞「動く」命令形語

尾)

3.「初しぐれ猿も小㝨をほしげなり」(助動詞「なり」)

4.「旅に病んで夢は枯野をかけめぐる」(切れ字なし)

句の何処に切机字があるかによって、句全体の重心が決定する。1の最初の2句は上5 末に、3句目は中7末に置かれた助詞「や」が切れ字である。切れ字は、言葉ではなく文字 であるから、使役の助動詞「す」の命令形「せよ」の「よ」が、同様に動詞の命令形「動け」の 「け」が切机字になる。3の「初しぐれ猿も小㝨をほしげなり」の切れ字は、句末に置かれ た断定の助動詞「なり」である。句末に切机字があるのは、どういうことなのか。句を直 
線的に詠み下しただけの単一構造の表現だとするのは間違いである。句末の切れ字は壁 のようなものであり、言い切った後に喚起される余情を、もう一度遡って一句全体に反 響させる複雑な重層構造の表現として捉え直さねばならない。周作人を除いて、この句 を漢訳した人はみんな「猿も小㝨を欲しがっている」と訳している。猿が人間並みに小蓑 を欲しがるはずなどない。「猿も小蓑を欲しげ」とある「げ」は、接尾辞で動詞や形容詞に ついて「いかにも……そう、……様子」の意味を表す。「そう見える」「そう思えた」と いう作者の気持ちを句にした。しかも、「猿も」とある「も」は類例を示す助詞である。初 時雨を前にして、いよいよ小蓑を身に付け、風雅な旅をする季節となったとわくわくし ているのは、芭蕉自身に他ならない。自分の思いは一言も触れずに、しかし、それこそ がこの俳句の核心だということを観賞させるために句末の切れ字がある。4の「旅に病ん で夢は枯野をかけめぐる」は芭蕉が死去する数日前に作った辞世の句の一つとされる。 俳句には稀にこのような切机字のない句というのがある。そういう句は17音が一気に いい下されて、この句のように力強い断言の句となる例が多い。濁流を駆け下るような 風雅を求める旅を生き、最後になって夢の中でもそれを続けようとしている。切れ字で はないのだから、句の終った地点での余情を静かに厳しく噛み締めればよいのだろ う。

助詞の「や」かな」と助動詞の「けり」の3語が、最もよく用いられる切れ字の代表とさ れている。こういう助詞や助動詞のような言葉は、孤立語の漢語にも屈折語の英語にも ない、日本語のような膠着語にだけある言葉である。その国の伝統詩とはその国のこと ばの可能性を鍛える場に他ならず、俳句の最重要の力ギが、切れ字すなわち助詞助動詞 などの働きにあるというのは、おそらく当然のことなのであろう。季語をどう訳すか という問題は、意味を持つ自立語に関連する問題だから、その言葉に文化的歴史的に対 応できる適切な漢語を探すことでおおよそは対応できる。しかし、切れ字の問題になる と、そのような助詞や助動詞などは漢語にはない。したがって、季語の際のような個々 の技術的な対応など不可能である。そこで翻訳という言語操作の原点に返って考え直し てみることにした。実際に芭蕉をどのように漢訳しているのか。今回の芭蕉の訳例か ら、切れ字の問題に関連し以下の4点を指摘しておきたい。

第1に、前章で指摘したように、初めは音数律の定型詩として訳したが、やがて音数 律に捉われない自由律詩として訳す者が出てきた点である。定型詩訳はリズムを生むの である。しかし、音数制限のため思うように訳せないことに不満を感じた人たちが、自 由律訳へと移行した。詩は韻律が生命ゆえに、直訳的逐語訳的なのは定型詩訳、意訳的 なのは自由詩訳である。定型詩か自由詩かは、直接に切机字の問題と重なるわけではな いが、翻訳する際の態度ないし方法の問題へ結び付くと考えると切れ字の問題に接して はいる。

第2に、本来は1行詩である俳句が、2行ないし3行で漢訳されている点である。改行 とは表現の展開を止めて、次の表現へ移行することであるがゆえに、これはそのまま切 
れ字の問題に重なっている。切れ字によって構成を複式化重層化するとしたが、切れ字 が展開の屈曲点だとすれば、改行は次の段階への転換点である。俳句の5・7・5は独立し た3部分と考えられがちで、確かにリズムの上では三つに分かれる。しかしそれは、 別々のものを重ねているわけではない。多くの場合、俳句は切机字によって意味的には 二分される。つまり「上5+中7・下5」か、「上5・中7+下5」のどちらかになっているのが 普通である。3行で訳す場合だと、リズムに結び付きやすく、2行訳だと意味内容に結び 付きやすい構成である。

第3に、本来の俳句の展開順を換えて翻訳する例が散見される点である。以下に具体 例を示す。

\begin{tabular}{|c|c|}
\hline 枯枝に鳥のとまりたるや秋の暮 & 彭恩華訳：秋日今向暮 枯枝有乌栖 \\
\hline \multirow[t]{3}{*}{ 初しぐれ猿も小蒿をほしげなり } & 鄭清茂訳：初逢时雨 \\
\hline & 猴子也想穿上 \\
\hline & 小小蓑衣 \\
\hline \multirow[t]{3}{*}{ 憂き我をさびしがらせよ閑古鳥 } & 姜文清訳：杜鹃鸟 \\
\hline & 送我忧怀 \\
\hline & 入闲寂 \\
\hline \multirow[t]{3}{*}{ 旅に病んで夢は枯野をかけめぐる } & 陳黎訳：羁旅病缠 \\
\hline & 梦如黑胶片, 回旋 \\
\hline & 于枯野唱盘 \\
\hline
\end{tabular}

俳句の5・7・5の順序を行分けに訳す際に、行順をあえて変えている。行分けに関係 することであるから、これも切れ字と無関係ではない。翻訳の句例は全部で42句ある が、その中の8句でこのような行順の変更がなされている。ここでは4人の例を挙げた が、その4人がそれぞれ2句ずつ行っている点からして、意識的な変更であることは確 かである。おそらく表現の展開を論理的に把握しやすくしたかったからだろう。

第4に、彭恩華と鄭清茂を除く人たちの漢訳には、くぎり符号が使われている。くぎ り符号とは、文脈を明らかにし、読解を正しく容易にするために使う表記上の符号であ る。使用例は、横書き用の句読点の(、。)、コロン ( : )、ダッシュ(一)などである。 様々な括弧や読み手の注意を引くための傍線、書き手の気持ちを表す感嘆符や疑問符な どもあるが、その種の符号は使われていない。くぎり符号の適用は、一種の修辞であ り、言葉を適切に用いるための技術の範囲内であり、切れ字的な働きはほとんどしてい ない。

異言語間の翻訳というのは、不可能といってもよいほどの困難な操作である。日本 語の切れ字のような機能は、漢語にはないのだから、辞書を引いてそこにある訳を付け ればよいということではない。現実にはある言語で表現されているすべての機能を、 もう一つの言語では表現できないことの方が多いだろう。そんな場合は機能があろうと 
なかろうと、移し換える言語での可能な範囲で、様々な方法を工夫しながら翻訳するこ とになる。ここで指摘した4点は、そのような意味で選択された工夫といってよいだろ う。

\section{5 おわりに一一国際化の問題}

19世紀の半ばから20世紀にかけ様々な日本美術が紹介され、その影響からジャポニ ズムと呼ばれる日本趣味が生じる。陶磁器や工芸品、浮世絵ら、日本美術への関心はフ ランスを中心に広く欧米の各国で見られた。ジャポニズムの意味を広くとれば、この他 に造園や歌舞伎、俳句などの文学にまで影響は及んでいる。ヴィジュアル的なものは理 解しやすかったろうが、俳句となると言葉の壁が存在し、翻訳が必要になる。当時の主 な紹介者の多くはラフカディオ=ハーン、 $\mathrm{B} ・ \mathrm{H} ・$ チェンバレン、カールニフローレンツ らお雇い外国人であり、俳句は三行ないし二行の無韻詩に翻訳していた。この最初の段 階から俳句は17音の音数律や切机字の用法を失っていた。その理由は、日本語と欧米語 との特質の相違に起因している。

しかも、そのように翻訳された「ハイク」だからといって、俳句独特の鮮明なイメー ジ、対象把握の方法、美しい単純さは必ずしも損なわれていなかった。その証拠とし て、現代詩の出発点ともいうべきイマジズム運動に、ハイクは大きく貢献したからであ る。俳句とイマジズム派の詩人たちの関係は、浮世絵と印象派の画家たちの関係に似て いる。さらに、ドイツの詩人リルケや、主著『ホモ・ルーデンス』な゙で遊びの意義を 解明したオランダの歴史学者ヨハン・ホイジンガ、映画芸術の確立に貢献したソ連の映 画監督セルゲイ・エイゼンシュテインら、時代を代表するような知性が俳句に興味を示 した。

こうした日本趣味に対し、否定しようとする見解も主張されている。近代日本を代 表する詩人の萩原朔太郎は、宮森麻太郎の英訳した俳句について次のように書いてい $ろ^{5}$ 。

多くの場合に、外国人に好評される日本の者は、真の純粋の日本ではなく、彼等 のフジヤマやゲイシヤガールの概念性に、矛盾なく調和して入り得る程度の、テン プラフライ式の似而非日本である。真の本当の日本のものは、彼等に理解されない ことから、却つて退屈されるばかりである。宮森氏の翻訳が西洋で受けてる理由 も、おそらくそれが八イカイ的俳句である為かも知机ないのである。

英文学者の宮森は、1930年に『AN ANTHOLOGY OF HAIKU ANCIENT AND

5 萩原朔太郎「詩の翻訳に就いて」(『生理』, 1933.11)。萩原朔太郎「詩の翻訳について」, 別宮貞徳編『日本の名 随筆翻訳』別巻45(作品社, 1994), p.64. 
$M O D E R N 』$ という英訳俳句集を刊行した。それが好評だということに対し、朔太郎が主 張したいのは、5・7・5のリズムや切れ字を失った“HAIKAI”に真の俳句性などないとい う否定論である。

第二次世界大戦後、俳句ブームの中心はフランスからアメリカへと移った。欧米で 禅が流行し、俳句はエゴレス一ポエム、ワードレス一ポエムとしても広まった。小学 館の刊行した『日本大百科全書』の「海外の俳句」に、以下ようなの解説( 執筆・乾裕幸)が ある。

俳句の理解は各国で当然異なるが、『ランダム八ウス・ポケット辞典』(1978)の「 HAIKU(1)日本の主要な詩形式で、高度にイメージ喚起力のある示唆(アリュージョ ン)を用いる三行詩。(2)この形式の詩」あたりが、代表的な見解であろう。(1)は翻 訳・研究の対象としての日本の「俳句」、(2)は外国人の創作する「ハイク」である゙。

これが海外における最近の平均的な俳句観なのだろう。俳句を日本の伝統詩として の「俳句」とその影響から成立し、他の国の人が自国語で創作する「ハイク」の二つに分け られている点に注目したい。中国でも日本の俳人たちとの交流の中で、「漢俳」と呼ばれ る5・7・5の新しい詩が創作され出している。その詩は如何にも中国の詩らしく韻を踏 む形式である。この二つの流机は、未来の国際化の中で、別個の二つの詩に分離してし まうか、あるいは統一された一つの詩になるか、興味深い問題である。世界的にみれ ば、俳句の主流はもはや「有季定型」ではなく、「無季自由律3行」がメインとなってい る。韻律や切れ字はそれぞれの言葉によって異なるし、季語も場所が変われば、合わな くて当然、最後に残る俳句の形式は、三行の短詩ということになるのだろうか。

\footnotetext{
参考文献

萩原朔太郎(1994[1933])「詩の翻訳に就いて」，別宮貞德編『日本の名随筆 別巻45 翻訳』東京：作品社，p.64. Hagiwara, Sakutaro(1994[1933]) Si no honyaku ni tsuite Nihon no maizuihitsu bekkan45 honyaku ed.Bekku.Sadanori,Tōkyō : sakuhin sha, p.64.

乾裕幸 (1984)「海外の俳句」『日本大百科全書18』東京：小学館, p.513. Inui, Hiroaki (1984) Kaigai no haiku Nihon daihyakka zensho18,Tōkyō : Shōgakkann, p.513.

陳黎·張芬齢 (2019)『松尾芭蕉俳句300 - 但願呼我的名為旅人』.北京：北京聯合出版公司. Chen, L · Zhang. F (2019) Songweibajiaopaiju300 · danyuanhuwodemingWeil vren,Beijing : beijinglianhechubangongsi.

姜文清 (2018)『日本俳句長編』,昆明：雲南人民出版社. Jiang. W. (2018) Ribenpaijuchangpian, Kunming： yunnanrenminchubanshe.

林林 (1983) 『日本古典俳句選』,长沙：湖南人民出版社. L in, L (1983) Ribengudianpaijuxuan. Changsha： hunanrenminchubanshe.
}

6 乾裕幸「海外の俳句」『日本大百科全書』18(小学館, 1984), p .513. 
彭恩華 (1983)『日本俳句史』、上海：学林出版社. Peng. E(1983) Ribenpaijushi, Shanghai : xuelinchubanshe.

田原 ·董泓每 (2019)『松尾芭蕉俳句选』,上海：上海文芸出版社. Tian, Y · Dong. H(2019) Songweibajiaopaijuxuan, Shanghai : shanghaiwenyichubanshe.

约翰·赫伊津哈 (2007 [1938])『游戏的人：文化中游戏成分的研究』,何道宽訳.广州：花城出版社. Johan · Hui, zinga (2007 [1938]) Youxideren : wenhuazhongyouxichengfendeyan Jiu[Homo Ludens] ,trans. He.D.Guangzhou : huachengchubanshe.

鄭民欣 (2008)『俳句的魅力一日本名句賞析』, 北京：外語教学与研究出版社. Zheng. M. (2008) Paijudemeili : ribenmingjushangxiBeijing : waivujiaoxueyuyanjiuchubanshe.

鄭清茂 (2017)『芭蕉百句』,台北：聊經出版事业有限公司. Zheng, Q (2017) Bajiaobaiju. Taibei： liaojingchubanshiyeyouxiangongsi.

周作人 (1998 [1921])「日本的詩歌」,鐘叔河編『周作人文類編7日本管窺』,長沙：湖南文芸出版社, pp.249-262 Zhou, Z(1998 [1921]) Ribendeshige ZhouzuorenwenLeibian7 ribenguanjian, ed.Zhong.SH,Changsha : hunanwenyichubanshe, pp.249-262.

周作人 (1998 [1923])「日本的小詩」.鐘叔河編『周作人文類編7日本管窺』、長沙：湖南文芸出版社, pp.290-298 Zhou, Z(1998 [1923]) Ribendexiaoshi Zhouzuorenwenleibian7 ribenguanjian, ed.Zhong.SH.Changsha : hunanwenyichubanshe, pp.290-298. 


\section{[付録］芭蕉漢訳例一覧(漢訳例を再度日本語訳にしたのは筆者である)}

1. 古池や蛙飛び込む水の音

(1)周作人訳 : 古池呀, 一一青蛙跳入水里的声音。

古池よ, 一一青蛙が水の中に飛び込んだ水の音。

(2)彭恩華訳 : 蛙跃古池内 静㵔传清响

蛙が古池の中に飛び込み静かな水だまりで澄んだ音が広がる

(3)林林訳 : 古池塘呀, 古池よ、

青蛙跳入水声响。 青蛙の飛び込んだ水音が響く。

(4)姜文清訳 : 古池呀, 古池よ、

青蛙跳进, 青蛙が飛び込んだ、

水音哟。 水の音よ。

(5)陳黎訳：古池一 古池——

青蛙跃进： 青蛙が飛び込んだ：

水之音 水の音

(6)田原訳 : 古池旁, 古池の傍、

青蛙一跃遁水音。 青蛙が一躍して水に入った音。

2. 名月や池をめぐりて夜もすがら

(1)周作人訳 : 望着十五夜的明月, 终夜只绕着池走。

十五夜の明月を見上げているらちに、終夜ただ池を回って歩いたのみ だった。

(2)彭恩華訳：中秋明月好

中秋明月が美しい

(3)林林訳 : 秋月明,

一夜绕池行。

(4)鄭清茂訳 : 明月当空

绕着池塘徘徊

佳兴终宵

终宵绕池行

終夜池を回って歩いた

秋の月が明るく、

一夜池を回って歩いた。

明月が中天にかかる

池を回って徘徊した

興趣が尽きない一夜

(5)姜文清訳：秋月哟,

秋月よ、

绕池清光,

池を回る輝き、

彻夜明。

終夜明るい。

(6)陳黎訳：中秋圆月：

中秋満月：

终夜——

終夜——

绕池

池を回った 
(7)田原訳：中秋明月,

围着池塘转,

通宵达旦。
中秋明月、

池を回り、

夜通し朝まで。

3. 初しぐれ猿も小蓑をほしげなり

(1)周作人訳：下时雨初, 猿猴也好像想着小蓑衣的样子。

時雨が降りはじめた頃、猿も小蓑を欲しがっている様子だ。

(2)林林訳 : 初寒降雨,

猿也想小㚃衣。

初寒雨が降ったが、

猿も小蓑を欲しがる。

(3)鄭民欣訳 : 入冬初降雨,

猿也思蓑衣。

冬に入り初めて雨が降ったが、

猿も袁を欲しがる。

(4)鄭清茂訳：初逢时雨

初めて時雨に遭い、

猴子也想穿上

猿も着たい

小小蓑衣

小さな蓑

(5)姜文清訳 : 冬雨下,

冬の雨が降り、

猿猴愿得,

猿が欲しがる、

小蓑衣。

小袁。

(6)陳黎訳 : 初冬第一场阵雨一

初冬初めてのにわか雨——

猿猴也想披上

猿も羽織りたがる

小蓑衣

小蒿

(7)田原訳：冬季秋雨,

冬の季節秋の雨、

猴子也想要蒿衣

猿も蒿を欲しがる。

4. 枯枝に鳥のとまりたるや秋の暮

(1)周作人訳：枯枝上乌鸦的定集了, 秋天的晚。

カラスが枯れ枝に群れている。秋の夕暮れ。

(2)彭恩華訳：秋日今向暮 枯枝有乌栖

秋日今暮れようとしている時 枯枝に鴉が止まっている

(3)林林訳：寒鸦宿枯枝,

深秋日暮时。

(4)鄭清茂訳：枯木枝頭

乌鸦元自栖止

秋日黄昏

(5)姜文清訳：枯枝头，

寒鸦栖于,

暮秋中。
寒鴉が枯枝に止まっている、

晚秋日の暮れる時。

枯れ木の枝の上に

鴉が周囲を気にせず止まっている

秋の日の黄昏。

枯れ枝の上に、

寒鴉が止まっている、

秋暮の中 
(6)陳黎訳：枯枝

寒鸦栖：

秋暮

(7)田原訳：乌鸦停枯枝,

秋日入黄昏。
枯枝に

寒鴉が止まっている：

秋暮

鴉が枯れ枝に止まっている、

秋の日の黄昏になる時。

5. 憂き我をさびしがらせよ閑古鳥

(1)周作人訳：多愁的我, 尽使他寂寞吧, 闲古鸟。

憂い多い私を、徹底的に寂しくさせてくれ、閑古鳥。

(2)鄭民欣訳：我心本孤凄，

布谷鸟声声鸣不停,

快快催岑寂。

(3)鄭清茂訳：幽憂此生

譲我分享寂寞

闲古岛鸣

(4)姜文清訳 : 杜鹃鸟,

送我忧怀,

入闲寂。

(5)陳黎訳：啊, 布谷鸟一

你让忧愁的我

更觉寂寞

(6)田原訳：把忧郁的我,

引向孤单与沉静,

布谷鸟鸣。
われの心が元々侘しいが、

声々に啼き止まらないほととぎす、

どんどんわれを寂しがらせてくれ。

深い憂鬱なこの身

寂寞を分かち合うため

閑古鳥が啼いている

ほととぎすが、

私に憂榃を送り、

閑寂の境地に入らせた。

あ、ほととぎす—

あなたが憂䍌な私を

更に寂しくさせた

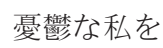

孤独と沈静に導いた、

ほととぎすが啼いている。

6. 塚もうごけわが泣く声は秋の風

(1)周作人訳 : 坟墓也动吧, 我的哭声是秋的风。

塚も動け、私の泣き声は秋の風だ。

(2)彭恩華訳 : 恍惚疑塚动

哭君秋风中

恍惚の中塚が動いているではないかと疑う 秋風の中君のために泣く

(3)林林訳 : 坟墓也震动, 塚も動き、

我的哭声似秋风。 私の泣き声が秋風のようだ。

(4)鄭民欣訳 : 悼君我悲恸,

君を悼む我の悲しみ、

化作秋风萧瑟声, さわさわ吹く秋風の音に化し、

坟冢也惊动。 塚も驚かせた。

(5)姜文清訳：坟冢摇,

塚が摇れている、 


$\begin{array}{ll}\text { 我之哭声, } & \text { わが泣き声が、 } \\ \text { 共秋风。 } & \text { 秋風とともに。 } \\ \text { 我的哭声是 } & \text { 私の泣き声は } \\ \text { 秋风, } & \text { 秋風だ。 } \\ \text { 坟墓也颤动 } & \text { 塚も震えている } \\ \text { 摹冢也动容, } & \text { 塚も感動した。 } \\ \text { 我的哭声, } & \text { 私の泣き声が、 } \\ \text { 化秋风。 } & \text { 秋風に化した。 }\end{array}$

7. 旅に病んで夢は枯野をかけめぐる

(1)周作人訳：病在旅中, 梦里还在枯野中奔走。

旅の中に病気になり、夢の中でも枯野を駆け巡る。

(2)彭恩華訳 : 病卧天涯人事绝 梦魂长绕枯野旋

病気で横になり天の果てに一人取り残され 夢の中魂が長く枯野をかけ めぐる

(3)林林訳：旅中正卧病,

梦绕荒野行。

旅中病床に伏しているが、

夢の中枯野をかけめぐる。

(4)鄭民欣訳：羁旅病床策， 旅中病床につき、

梦绕荒野枯。 夢が枯野をかけめぐる。

(5)鄭清茂訳：病缠羁旅 旅中病気におかれ

梦中梦游荒原 夢の中枯野を夢遊し

到处奔走 此処彼処奔走する

(6)姜文清訳：羁旅人，

病中幽梦, 旅人、

绕枯野。 病気の中深い夢に落ち、 枯野をかけめぐる。

(7)陳黎訳：羁旅病缠： 異郷に身を寄せ病気におかれた：

梦如黑胶片, 回旋夢は黒いフイルムのように、廻旋する

于枯野唱盘枯野のレコード盤を

(8)田原訳：病倒旅途中，旅中に病気で倒れて、

梦里荒野狂奔中。夢の中枯野を奔走している。 